\title{
Where should I publish my next manuscript on Limnology?
}

\author{
Onde eu devo publicar meu próximo manuscrito em Limnologia?
}

\author{
Juan Josè Neiff*
}

${ }^{1}$ Centro de Ecología Aplicada del Litoral - CECOAL, Consejo Nacional de Investigaciones

Científicas y Técnicas, Universidad Nacional del Noreste, Ruta Prov. 5, Km 2,5, 3400, Corrientes, Argentina

*e-mail: jj@neiff.com.ar

Cite as: Neiff, J.J. Where should I publish my next manuscript on Limnology? Acta Limnologica Brasiliensia, 2016, vol. 28, e13.

\begin{abstract}
When we need to spread the limnological knowledge, arises an issue that is not less than: where to publish our next article? In recent decades, the main element of evaluation are the "papers" and the sentence "publish or perish" haunts many scientists. It is imperative that researchers to share their discoveries or new knowledge. The dilemma arises because the scientific agencies (led by scientists) have installed what I call prestige system in which researchers needs a number of articles published in mainstream journals with highest positions in the ranking to progress in their scientific carrier. This determines a strong pressure on the subjects under investigation, in the allocation of resources and, sometimes, comes to desperation to publish. It is also producing the neglect of regional issues hardly find place in those journals and end up published in journals unreliable. The dissemination of the limnological topics in Latin American journals gradually lost prominence. In my opinion, it's necesary to spread the results for the people that paying our salaries and supports our projects. Put another way, publish in good local journals, without prejudice to also publish in journals of high international ranking. Scientific production should be evaluated for their trascendence, by his transforming power and not just by impact factors used today by many agencies.
\end{abstract}

Keywords: impact factor; Latin American Journals; scientific crises; transcendence of science; scientific innovation.

Resumo: Quando precisamos difundir o conhecimento limnológico, surge uma questão que não é menos importante: onde publicar o nosso próximo artigo? Nas décadas recentes, o principal elemento de avaliação são os artigos científicos e a sentença "publicar ou perecer" assombra muitos cientistas. É imprescindível que os pesquisadores compartilhem suas descobertas ou novos conhecimentos. O dilema surge porque as agências de fomento (lideradas por cientistas) têm instalado o que eu chamo de sistema de prestígio em que pesquisadores precisam de um número de artigos publicados em revistas com as mais altas posiçóes no ranking para progredir em sua carreira científica. Isto determina forte pressão sobre os objetos de investigação, na alocação de recursos e, às vezes, leva ao desespero em publicar. Esta pressão também negligencia a atenção sobre temas de interesse regional que dificilmente encontram lugar nestas revistas e acabam sendo publicados em revistas pouco confiáveis. A divulgação de temas limnológicos em revistas latinoamericanas está gradualmente perdendo importância. Na minha opiniáo nós limnólogos temos que divulgar nossos resultados para a sociedade que paga nosso salário e sustenta nossos projetos. Portanto, eu considero que devemos publicar nossos resultados de pesquisa em boas revistas locais, sem prejuízo de publicar também em revistas de elevado ranking internacional. A produção científica deve ser avaliada quanto à sua transcendencia e pelo seu poder transformador da realidade e nấo somente por fatores de impacto usados hoje por muitas agências de fomento.

Palavras-chave: fator de impacto; Revistas latinoamericanas; crise científica; transcendência da ciênca; inovação científica. 
The results of scientific research are a valuable asset for both the researcher and society. Journal selection has now become a strategic process. Who will the readers be? Who owns the information? How can this knowledge result in greater benefits to those who finance the salary of the researcher? Why choose a regional journal published by an association of scientists?

My opinion on these issues is laid out below.

\section{Why Do Scientists Publish Papers?}

Scientific papers are the vehicle to disseminate the results of science. However, as Kreimer (2012) says, they are also rhetorical instruments, discursive elements to convince the rest of society. The sum of scientific papers does not constitute science itself, and they do not always constitute the truth. When a manuscript can convince colleagues, the results are published, and to the extent that these results are mentioned in articles that other researchers publish, true consensus arises, which obviously is not necessarily the truth. Historically, there was consensus that the Earth was flat. Afterwards, consensus evolved around the idea of a spherical earth. Today, we know the earth to be a geoid, which is flattened at the poles.

Scientific papers are the primary instruments to disseminate new knowledge and discoveries, new methods, or to compile information on a specific topic. To this end, it is important that our message reaches the largest possible number of people interested in that topic by using the best means at hand.

However, those who work in science know that the institution for which they work (university, agency, company), regularly qualifies our activity through the number of scientific papers published. Thus, we publish papers, because if we do not publish, we lose our position in the scientific system. As the saying goes, "publish or perish".

Desperation to publish as a means of success in the system has produced dishonest behaviours. Publishing the same results in various formats, publishing in hijacked journals (Jalalian \& Mahboobi, 2013), cases of scientific fraud, which have been found in different parts of the world (Alinovi, 2010), have been on the rise. This seemingly urgent need to accumulate papers to prove the quality of research has distorted the significance of the scientific concept of product and has broken many ethical barriers of the society to which the researcher belongs.
The more papers published by a researcher, the greater the prestige and the better he or she will be known and valued by the system. Furthermore, these researchers will have access to more resources to purchase and renovate measuring instruments and fund their research; they will also have access to a greater number of colleagues and be able to participate in important international conferences. All of this leads to more resources to produce more papers that will increase the prestige of the researcher in a process of constant positive feedback (Kreimer, 2012).

As a consequence of this prestige-system, the number of scientific journals has grown exponentially since the middle of the $18^{\text {th }}$ century up to its progressive saturation at the end of the last century. The number of existing periodic scientific publications in the world has been estimated to be in the order of 50,000 journals, of which approximately 20,000 originate in Latin America and the Caribbean, including Spain and Portugal. (Laufer, 2007a). Approximately $0.5 \%$ of these journals include the collections of Scielo and Redalyc, and approximately one in five hundred were included in the indices of so-called mainstream science, that is, in the indices of the ISI, universal indicator, Scielo and Redalyc (Laufer, 2007a). It is noteworthy that Acta Limnologica Brasiliensia is an internationally qualified journal, one of the few in the Limnology field in Latin America.

While there is no fixed mathematical formula, the higher the number of published articles, the greater the chances that an author will be cited by the scientific community. More citations, furthermore, result in a greater "impact factor" and a better chance of getting resources for research (Monge-Nájera, 2014).

Nevertheless, the impact factor has been challenged with increased frequency in recent years. For example, its calculation assumes that citation data are reliable and available for scientific scrutiny; however, bibliographic errors are frequent and the citation data are not transparent, as Monge-Nájera \& Yuh-Shan (2016) has noted.

However, we must not forget that the impact factor, as measured by the Web of Science, was never meant to be used as an evaluation of the importance of research, and, originally, it had no financial influence. Funding was unrelated to citations (Harter \& Hooten, 1992; Gregory, 2004; Monge-Nájera \& Yuh-Shan, 2016). 
In some cases, it is recommendded that researchers and evaluators of project funding agencies and publications use "non-core journals" to obtain a wider and more representative view of science (Crawley-Low, 2006) and that they check the quality of the articles themselves. In some cases, high citation values may be indicative of an article that is controversial or clearly wrong (Monge-Nájera \& Yuh-Shan, 2015).

The problem with this prestige-system is that researchers in tropical countries working in lakes or tropical rivers usually forget to publish in their regional journals after reaching sufficient prestige. These regional journals should be the most successful in spreading results of aquatic ecosystems to their universities within the region in a way that ensures that these results will reach government agencies.

Because the evaluation system in Latin America and perhaps in the rest of the developed world is based on prestige, funding agencies and even universities and leading researchers recommend their colleagues to publish in journals of high impact factor because your future depends on the impact factor reached.

The prestige-system is the most effective way to destroy national and regional journals because it discourages researchers to publish in journals with low impact factor. The proof is that Latin American journals are gradually disappearing, even those with a historical trajectory of great prestige. Research of regional interest such as regional inventories of lakes, rivers, flora and fauna also gradually disappears as the attention shifts towards limnological and ecological issues that are priorities in the northern hemisphere, as these results are known to have less drawbacks for publication.

The transcendence of scientific results depends only in part on the journal. If the result (content) is published in a journal with low impact factor but has been long awaited for by society (e.g., a vaccine), it will be quickly engaged with and disseminated by other means.

Along the same lines, the effectiveness of a publication is a fundamental attribute that obviously does not depend on a journal's impact factor. Farmers who produce flowers, tomatoes or strawberries know that the value of their product can be five times higher if the product arrives at the market before its competitors. So, too, in science. The researcher who proposes a new method or trophic circuit or presents a discovery has greater chances of success.

\section{Why Are the Regional Journals of Latin America so Important?}

Since humans began walking on two legs, limnological/ecological knowledge has been essential for life. However, that knowledge transmission has occurred differently throughout history.

Scientific researchers have long had either the necessary resources to carry out their discoveries or have been supported by patrons. Thus, scientific structures existed and new knowledge or discoveries were transferred to society erratically. Even today, we are still finding studies by Leonardo da Vinci and other great creators. Beginning in the seventeenth century, scientific societies and research went from being a private activity to forming part of the public domain. Research began to be financed by the government, with the inescapable condition that researchers communicate their results to society. Therefore, society, through taxes paid to the government, pays the salary of researchers and has the right to use the results of this research.

Thus, it is important for research results to reach society in understandable language. For this reason, there is an interest in journals reaching a wide audience, in addition to those targeted to the scientific community. Latin American journals of Biology, Ecology, Limnology, among others, have prestigious Editorial Boards composed by scientists with major national and international reputations. Currently, many of them, such as Acta Limnologica Brasiliensia, Brazilian Journal of Biology, Interciencia, Journal of Tropical Biology, Revista Chilena de Historia Natural, Neotropical Ichthiology, Nauplius, among others, have a reliable editorial management.

In many cases, the management process is performed through an Intranet or by other electronic means, and authors are notified when their manuscript goes through the different stages of evaluation.

Generally, manuscripts go through all assessment stages before the Editor decides whether the manuscript is publishable or not.

Only the Editor knows the name of the authors submitting a manuscript. The authors do not know their reviewers, and reviewers do not know the authors. This guarantees that the main evaluation parameter is the quality and newness of the content of the manuscript submitted to the journal.

The Editor may have Associate Editors for the publication of special issues. In these cases, an issue will be compiled from a congress, symposium, or review of a topic. These thematic publications 
are very important because they compile the existing knowledge on a lake system or watershed, which acquires historical importance for future generations of researchers in each country or region. The disappearance of regional journals leads to the fragmentation of knowledge as it becomes dispersed in the large universe of publications.

Some journals have an electronic version that is open access, which favours the spread of discoveries, even for people who cannot afford to access the printed version.

Many of these journals are issued by scientific societies, which carries greater reliability.

\section{Is It Better to Publish in Journals of Developed Countries rather than in Latin American Journals?}

One of the ailments affecting science in our region and common to all "developing" countries is the scarcity of scientific journals with quality and visibility levels that inspires our scientists to publish in them and to do so with pride and satisfaction. The attitude of many of our researchers leaves much to be desired. The disregard for local journals and the preference for publication in and citation from first world journals, even in the case of their own papers, will cause these journals to progressively disappear (Laufer, 2007b).

The most reliable journals are those belonging to scientific societies, major publishers and especially those with a long history. In fact, journals with the highest indexing publish more issues per year and have more readers. These conditions result in efficient sales of each issue and do not depend on the subsidies of special interest groups that might exert influence on a journal.

In recent decades, numerous pirate journals have appeared because of the following factors:

- the behavior of some researchers to publish urgently and accumulate papers claimed for the prestige-system;

- have no affiliation with any known scientific society;

- have Editors who are not recognized scientists;

- have Editorial Boards composed of unknown people with dubious affiliations;

- do not have a reliable publishing management process;

- do not have a rigorous referee selection process;
- have no known physical residence or affiliation to any university or institution;

- have high publication costs;

- accept or reject manuscripts using the author/s affiliation as the main indicator of manuscript quality.

Some studies have highlighted erroneous editorial management criteria in well-established international journals (Sokal, 1996). According to Dadkhah et al. (2015a), the main parameter for the acceptance or rejection of a scientific manuscript is the affiliation of the author of the manuscript, which is discriminatory. Academic values are facing many challenges, such as bogus impact factors (Jalalian \& Mahboobi, 2013), fake conferences and other dubious schemes. The publication of scientific results must avoid discrimination based on affiliation status, or researchers may fall prey to pirate journals or predatory publishers. There are some contributions dealing with academic fraud that present some guidelines for authors (Dadkhah et al., 2015b; Tin et al., 2014).

The study by Dadkhah et al. (2015a) noted that some peer review journals care about author affiliation rather than paper content and publish any paper belonging to authors with prestigious affiliations, such as department chairs or heads of universities or large companies. These journals do not have peer reviews for these papers and their responses to these authors arrive quickly.

The most valuable jewel of a researcher is their scientific production. So it is necessary to ensure that production is published through a fair process.

\section{Should We? Or Can We Publish in English?}

This is an old discussion, and it seems like an accepted truth by the editors of scientific journals that "the language of science is English". However, this depends largely on who the recipient of the scientific message is. Even today, the scope of science is limited by language, especially for our students, who should ensure the widest possible dissemination for their scientific output.

A scientist's choice of language is motivated by his or her desire to exchange ideas with his or her peers; this choice should not be the subject of hard restrictions, especially in Latin American journals.

Analyses by publishers are erroneous because the premises are based on a confusion between vehicle and content. In scientific writing, the medium is not the message. Worse, this type of decision 
implies that papers written in English are good and papers written in Spanish, Portuguese or other languages are mediocre and not worth reading. Researchers must react and not allow scientific expression to be monopolized by a foreign language (Bergeron, 1990). Each society has the right and the responsibility to demand that its scientists explain and transfer their knowledge to their milieu.

The reason to publish in English, even in journals of Spanish-speaking countries, is that authors must disseminate their results throughout Latin America (Ryder, 2001). However, a recent analysis from The Revista de Biología Tropicall International Journal of Tropical Biology and Conservation (founded in 1953), which receives manuscripts in several languages, demonstrated that Spanish and English articles were nearly equal in numbers and that citation of English articles was only slightly higher (Monge-Nájera \& Yuh-Shan, 2016).

Papers on tropical Limnology should be published in the native language and give preference to regional journals to reach the scientific community and authorities involved with tropical rivers, lakes and wetlands management from the country of origin of the reported results.

The main goal of a researcher should not be producing an article that only receives many citations in other journals. Rather, the content of their publication should aim to produce a real transformation in the society that sustains their work.

Obviously, there are a variety of results, methods, concepts, that can also be of much international interest in northern hemisphere countries, and it is important to make a publication available to English readers. This should be done however, without neglecting the need to communicate the results of their research to the local and regional community in their own language.

The process of writing and editing an article in good English requires a substantial amount of time. This is justified only when the results have real value to universal science and becomes irrelevant when it only adds nuances to already established knowledge.

In addition to these comments, requiring publishers to publish only in English is a major obstacle for many authors and has a negative effect on the number of manuscripts submitted in Latin American journals. Interciencia, Revista de Biologia Tropical and other journals allow authors to choose the publication language. English manuscripts do not reach 20\% (Laufer, 2015), revealing the difficulty of writing in that language.
There are limitations concerning English language capabilities, which can be observed in authors as well as in readers, especially students. Nevertheless, the language has little or nothing to do with the quality of the published material, which derives from factors inherent to the intellectual conditions of researchers and the level of scientific and technological development of their society (Laufer, 2007b).

\section{Conclusion}

Those who submit manuscripts only to foreign Limnology journals underestimate the socialization of knowledge at the regional level. It constitutes an unfair attitude on behalf of many Latin American scientists, who prefer quoting mainstream papers rather than refer to the efforts of their colleagues in institutions of developing countries. So does the tendency of some to underestimate any evaluation system based on foreign patterns (Laufer, 2009).

Being aware of discrimination due to the geographical origin of manuscripts or the researcher's affiliation and knowing about the existence of hijacked journals, reviewers with dubious expertise and/or insufficient knowledge of regional ecosystems, is of paramount importance. Journals of scientific societies are currently the best guarantee for scientists as well as for readers.

Tropical research on Limnology, Ecology, and even Biology does not have the rapid shelf-life typical of medical research. For this reason, the impact factor misses most of citations for tropical journals in these sciences, which are made after the two-year window used by the Web of Science. This issue is especially damaging for the Latin American journals because most that address Tropical Biology, Ecology and Limnology are never factored in when citations are counted for by the Science Citation Index (Monge-Nájera \& Yuh-Shan, 2015, 2016). In my case, the most cited paper in 40 years was published in Interciencia, in Spanish, in 1990 and is currently still being read and cited by my colleagues from several countries.

I suggest the following general framework to plan for the publication of research results:

1. Choose the most prestigious scientific journal as possible related to the subject of the manuscript, especially journals belonging to scientific associations and societies.

2. Choose a journal that preferably has a rapid process of evaluation and publication, 
3. Publish your results in your language in a regional journal and make a synopsis of its results in English, in a main-stream journal.

Finally, do not despair. Publish only news that may help others because science is a service to society and not a means to make your image.

\section{References}

ALINOVI, M. Historia universal de la infamia cientifica. Buenos Aires: Siglo XXI Editores, 2010. 206 p.

BERGERON, M. Louis Pasteur and the universality of the science. Interciencia, 1990, 15(1), 5.

CRAWLEY-LOW, J. Bibliometric analysis of the American Journal of Veterinary Research to produce a list of core veterinary medicine journals. Journal of the Medical Library Association, 2006, 94(4), 430-434. PMid:17082835.

DADKHAH, M., ALHARBI, A. M., AL-KHRESHEH, M H., SUTIKNO, T., MALISZEWSKI, T., JAZI, M. D., SHAMSHIRBAND, S. Affiliation oriented journals: don't worry about peer review if you have good affiliation. International Journal of Electrical and Computer Engineering, 2015a, 5(4), 621-625.

DADKHAH, M., JAZI, M. D. and PACUKAJ, S. Fake Conferences for Earning Real Money. Mediterranean Journal of Social Sciences, 2015b, 6(2), 11-12. http:// dx.doi.org/10.5901/mjss.2015.v6n2p11.

GREGORY, A.T. Jewels in the crown: the Medical Journal of Australia's 10 most-cited articles. The Medical Journal of Australia, 2004, 181(1), 9-12. PMid: 15233603.

HARTER, S.P. and HOOTEN, P.A. Information-science and scientists: JASIS, 1972-1990. Journal of the American Society for Information Science, 1992, 43(9), 583-593. http://dx.doi.org/10.1002/(SICI) 1097 4571(199210)43:9<583::AID-ASI1>3.0.CO;2-O.

JALALIAN, M. and MAHBOOBI, H.R. New corruption detected: bogus impact factors compiled by fake org anizations. Electronic Physician, 2013, 5(3), 685-686. http://dx.doi.org/10.14661/2013.685-686.

KREIMER, P. Sobre el nacimiento, el desarrollo y la demolición de los papers. In D. GOLOMBEK.
Demoliendo papers: la trastienda de las publicaciones cientificas. 2nd ed. Buenos Aires: Siglo XXI Editores, 2012, pp. 7-22.

LAUFER, M. La cultura de la publicación científica (I). Interciencia, 2007a, 32(8), 501.

LAUFER, M. Publiquemos en nuestras revistas, leámoslas y citémoslas. Interciencia, 2007b, 32(3), 141-143.

LAUFER, M. Evaluar de veras nuestra ciencia. Interciencia, 2009, 34(11), 761-763.

LAUFER, M. Cantidad vs. calidad. Interciencia, 2015, 40(12), 813.

MONGE-NÁJERA, J. and YUH-SHAN, H. Bibliometry of Panama publications in the Science Citation Index Expanded: publication type, language, fields, authors and institutions. Revista de Biologia Tropical, 2015, 63(4), 1255-1266. http://dx.doi. org/10.15517/rbt.v63i4.21112.

MONGE-NÁJERA, J. and YUH-SHAN, H. Bibliometry of the Revista de Biología Tropical/International Journal of Tropical Biology and Conservation: document types, languages, countries, institutions, citations and article lifespan. Revista de Biología Tropical, 2016, 64(3), 1233-1335. http://dx.doi. org/10.15517/rbt.v64i3.22142.

MONGE-NÁJERA, J. La invalidez del factor de impacto como indicador del impacto de las revistas científicas latinoamericanas. Revista de Biología Tropical, 2014, 62 (1), 407-412.

RYDER, E. Predominio del idioma inglés y no de la lengua nativa, el espańol, en trabajos de impacto en salud pública en venezuela. Interciencia, 2001, 26(12), 619-623.

SOKAL, A. A physicist experiments with cultural studies. New York: New York University, 1996, pp. 1-6.

TIN, A., IVANA, B., BILJANA, B., LJUBICA, I. B., DRAGAN, M., DUŠAN, S. Predatory and fake scientific journals/publishers-a global outbreak with rising trend: a review. Geographica Pannonica, 2014, 18(3), 69-81.

Received: 04 May 2016 Accepted: 16 September 2016 